\title{
Training in Neurology: How Lessons Learned on Teaching, Well-being, and Telemedicine During the COVID-19 Pandemic Can Shape the Future of Neurology Education
}

\author{
Stefano Sandrone, PhD, Dara V.F. Albert, DO, MEd, ${ }^{*}$ S. Richard Dunham, MD, ${ }^{*}$ Jessica Kraker, MD,* \\ Ika Noviawaty, MD,* Michael Palm, MD,* and Hani Kushlaf, MD \\ Neurology ${ }^{\circledR}$ 2021;96:e3007-e3010. doi:10.1212/WNL.0000000000012010
}

\author{
Correspondence \\ Dr. Sandrone \\ sandrone.stefano@ \\ gmail.com \\ or Dr. Kushlaf \\ hani.kushlaf@uc.edu
}

\section{MORE ONLINE}

\section{COVID-19 Resources}

For the latest articles, invited commentaries, and blogs from physicians around the world NPub.org/COVID19

\section{Introduction}

The past year witnessed remarkable shifts in education due to the COVID-19 pandemic. Although each residency training program had to confront unique challenges, there are shared lessons to be learned.

\section{Teaching}

\section{Background}

With the closure of lecture halls and social distancing measures, teaching sessions were rapidly moved online. They took the form of live (synchronous) activities, prerecorded (asynchronous) lectures, or a mix of the two. Prereading materials were often assigned before the lecture, following the flipped classroom approach. ${ }^{1}$ Small group discussions took place in online platforms such as WebEx, Zoom, and Microsoft Teams, in addition to outpatient phone/video visit shadowing, online cases, real-time polling, and written assignments.

\section{Positive Experiences}

Residents and faculty no longer have to travel, and they can attend or give a lecture from any location. Virtual platforms enable trainees to access live/on-demand lectures from different educational centers, facilitating intercenter collaborations and knowledge exchanges at both resident and faculty level. For instance, a rapid, volunteer cross-institutional lecture series for neurology residents was delivered virtually at the beginning of the COVID-19 pandemic. $^{2}$ This program included open-sourced didactics available to neurology learners across the country and featured invited neurology educators from any program across the United States. ${ }^{2}$ Another

\footnotetext{
*These authors contributed equally and are listed alphabetically. The first and last author are co-senior authors.

From Imperial College London (S.S.), UK; A.B. Baker Section on Neurological Education (S.S., D.V.F.A., S.R.D., J.K., I.N., M.P., H.K.), American Academy of Neurology, Minneapolis, MN; Department of Pediatrics, Division of Child Neurology (D.V.F.A.), Nationwide Children's Hospital and the Ohio State University, Columbus; Washington University in Saint Louis (S.R.D.), MO; Department of Clinical Neurosciences (J.K.), Tulane University School of Medicine, New Orleans, LA; Department of Neurology, Epilepsy Division (I.N.), University of Massachusetts Medical School, Boston; Department of Neurology (M.P.), University of Texas Health Science Center at San Antonio; and Department of Neurology \& Rehabilitation Medicine (H.K.), University of Cincinnati, $\mathrm{OH}$.

Go to Neurology.org/N for full disclosures. Funding information and disclosures deemed relevant by the authors, if any, are provided at the end of the article.
} 
example is the "14-day Quarantine Curriculum," a live series focused on foundational elements in psychiatric neuroscience, via a mixture of self-learning and interactive experiences, now freely available online. ${ }^{3}$ To maximize safety with physical distancing, even hospital ward teaching can occur remotely (remote precepting) via 3 or more-way phone and video visits, and family members can assist with the neurologic examination in video visits. ${ }^{4,5}$ Residents and students can shadow faculty during clinic encounters by attending synchronous phone and video visits.

\section{Negative Experiences/Challenges}

During the lockdown, trainees' exposure to bedside teaching and elective procedures, including invasive EEG and cortical mapping, was minimized. Furthermore, many hospitals experienced a decrease in non-COVID-19-related admissions ${ }^{6}$ : having a lower inpatient neurology census may result in fewer clinical experiences for neurology trainees. Remote learning might be less ideal for training neurologic skills, such as the neurologic examination, nerve conduction studies and EMG, botulinum toxin injection, lumbar puncture, and case simulation. The act of recording lectures might discourage attendance, engagement, and interaction. It also leads to new questions on privacy regulations: an intentional or unintentional diffusion of recorded material can put at risk the confidentiality of patients' data or of participants in the virtual meetings. These challenges, if not tackled, can compromise the knowledge and safety of the people involved in teaching activities.

\section{Action Items}

Lectures, grand rounds, and international conferences can be organized online. Virtual and distance learning can be an ideal environment for developing specific tasks via the integration of active learning activities, such as analyzing data, writing an abstract, and preparing a scientific poster or a set of slides. ${ }^{7}$ Organizing faculty development training sessions represents an excellent chance to talk about teaching and brainstorming solutions to common problems. Exploiting the benefits of online learning might deepen the pool of educators, provide the learners with a broader education, and widen participation by residents, faculty, and experts worldwide. Moving events online might contribute to diminishing the carbon footprint ${ }^{8}$ and reducing the associated cost, which, in turn, might increase access to educational opportunities. However, sharing a common space and overlapping paths increases the propensity to collaborate and the likelihood to get new collaborative grants funded. ${ }^{9}$ Therefore, institutions and event organizers should try to arrange places, in the real or online world, where attendees can safely gather and interact. Virtual and augmented reality might be instrumental in recreating the feeling of in-person collaborations and physical proximity, ${ }^{10}$ although data safety represents a new frontier for institutions and regulators. Educational studies will need to assess similarities and differences on the effect of mentoring and networking in-person vs online. Looking forward, a mix of in-person and virtual lectures may flexibly capture the best of both worlds, and could be a step towards personalized teaching.

\section{Well-being}

\section{Background}

The pandemic adds uncertainty to previously exacerbated situations. Before the pandemic, the lack of work-life balance was associated with an increased risk of burnout and reduced career satisfaction in neurology residents and fellows. ${ }^{11}$ Moreover, due to the widespread presence of technological devices in our daily life, the boundaries between personal and professional life are even more blurred. Exposure to patients with COVID-19 reportedly increases physician trainee stress and burnout. ${ }^{12}$

\section{Positive Experiences}

To improve well-being, or decrease burnout, strategies to promote wellness and flexibility should be implemented. Changes to inpatient neurology team structure can minimize exposure risk for residents and faculty, along with the assistance with home arrangement for those without alternative childcare. Debriefing about difficult situations may help, even at a distance. Peer and faculty mentoring schemes can be moved online as well. To boost resident morale and support local businesses, meals for the inpatient services can be provided. Scheduling regular or semiregular virtual meals or gatherings might help reduce isolation, contribute to team building, and create new habits. The weekly in-person didactics were often a chance for the residents and leadership to gather, strengthen relationships, and check on each other. In their absence, virtual social events can be planned to maintain a positive sense of well-being and build a strong sense of belonging. Online activities, to which families and friends can be invited, can include card games, role-playing activities, and quiz and trivia contests. Welcome, farewell, and retirement events can be easily held online. Furthermore, a weekly or biweekly section or departmental meeting can be planned to convey and summarize updates. Centralized email updates about new workflows, staffing, support, and encouragement can build trust: coordinated communications emphasize a community focus, but without marginalizing individual needs. Residents can jointly establish or revamp a social media presence for the program: this gives them a goal and a sense of purpose, aside from creating new group chats to support each other. Newly arrived residents can deliver outreach or public engagement activities with local communities: this might favor their integration in the new environment and inspire the audience.

\section{Negative Experiences/Challenges}

While ensuring a high level of participation in the activities mentioned earlier is challenging, it can be the most critical factor in ensuring a successful outcome. Poor attendance, reluctance to switch the camera on, or constant disengagement in the life of the section/department can be flagged to the program director or wellness committee. Residents and faculty members' anxiety is linked to uncertainty towards an uncharted situation: fears of exposure and falling ill, in addition to the negative financial effects of COVID-19, are further pressures. Learners and faculty may be balancing personal medical 
conditions, isolation, or additional family needs, or may feel overwhelmed by workplace risk without compensation or choice.

\section{Action Items}

Listening to individual and group needs is the first local step to target a wide range of situations. Collaboration with trainees' well-being committees helps ensure the services offered meet trainees' expectations and needs. Mindfulness-based interventions proved to effectively reduce distress and improve wellbeing in health care professionals and trainees. ${ }^{13}$ Well-being and support for neurology trainees need to be expanded and emphasized: wellness resources (i.e., in the form of free counseling, mindfulness, and support groups) should be mandatorily available through the hospital and the medical schools. Wellness-related opportunities need not only to be organized, but also signposted, shared as acceptable practices when successful, and critically evaluated with educational research. Educators also need to be vigilant in conducting long-term follow up for COVID-19 effect on wellness and burnout level.

\section{Telemedicine}

\section{Background}

The COVID-19 pandemic has a significant effect on the delivery of neurologic care via telemedicine platforms in several neurology practices. Telemedicine had a role in our health care system before the pandemic, but had not been widely adopted and was rarely a dedicated component of residency. Residency programs had to rapidly provide education and exposure that would allow their trainees to acquire the skills necessary to shift care.

\section{Positive Experiences}

The American Academy of Neurology Telemedicine Work Group recognizes the noninferiority to in-person evaluation and found evidence of benefits, including reduced costs, improved access, and timeliness of care. ${ }^{14}$ Telemedicine has an additional advantage in access to subspecialty care, such as stroke, where its use was more widespread before the pandemic. Its expansion due to COVID-19 proved to be a valuable tool to broaden access to neurologists and reduce the wait times to get an appointment and neutralize the travel time to the neurologic center. The sudden adaptation of telemedicine actively involves trainees, and many of them recognized this benefit. Moreover, programs incorporating teleneurology teaching in the curriculum showed augmented proficiency and accuracy. ${ }^{15}$

\section{Negative Experiences/Challenges}

Residents had to rapidly learn the use of synchronous telemedicine, which includes evaluating the patient's living situation, including multiple family members/caregivers in the visit, and coordinating and educating various health care team members regarding evaluation and management. The ability to perform a neurologic examination over video might initially be perceived as a challenge, but then can become a newly acquired skill, with positive aspects for training and development. Trainees experienced the limitations of telemedicine, such as patients' challenges in understanding instructions, practical limits for remote examination, logistics of interpreter services, and inability to reprogram devices such as responsive neurostimulators, vagus nerve stimulators, or deep brain stimulators.

\section{Action Items}

Telemedicine can be easily integrated into the curriculum. Curricula incorporating changes as a reaction to a mutated clinical setting can provide a stronger, more authentic educational experience. Medical education research can evaluate the creation of milestones to be adapted to various environments. ${ }^{15}$ Developing standardized, rigorous assessment and evaluation of telemedicine, via national and international collaborations, can guide curriculum review and trigger the definition of data safety regulations. Telemedicine exposure can also sprout

Figure Good Practices in Teaching, Well-being, and Telemedicine During the COVID-19 Pandemic and Recommendations to Improve Neurology Education

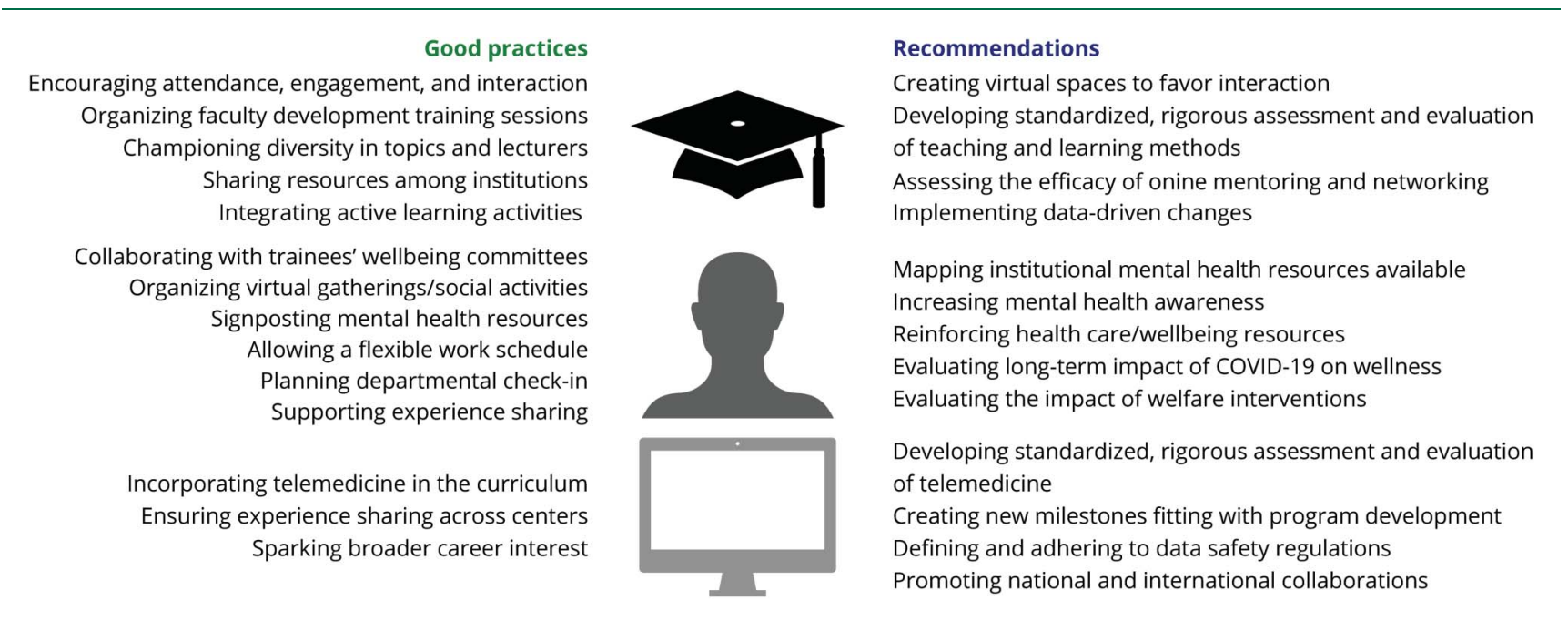


broader career-related interests, including global health, and consideration of less conventional career paths, such as remote monitoring and telemedicine. Telemedicine may be here to stay beyond the pandemic, and these skills will be beneficial for trainees.

\section{Discussion}

The restrictions implemented in response to the COVID-19 pandemic require rapid integration of curricular changes. The pandemic is bringing to light gaps already present in neurology education and has further exacerbated difficult situations. While a return to normal is not on the horizon, the ideas and knowledge gained from these experiences are invaluable. Sharing good practices and reflecting on the lessons learned during the COVID-19 pandemic can improve the present and the future of neurology education (figure). Many of the lessons learned can be utilized to improve training further, as current and future neurology education will likely consist of a hybrid blend of in-person and virtual experiences. More widespread input of shared experiences in well-being, education, and clinical training could help develop best practices.

Across the 3 sections discussed in this article, a strong need for further educational research emerged. Collecting information through focus groups, workgroups, or surveys of learners and educators is essential to inform best practices, provide additional recommendations, and implement data-driven changes in neurology education. Developing standardized, rigorous evaluation of teaching methods and telemedicine, reinforcing wellness resources, and promoting international collaborations can shape the future of neurology education and, in turn, contribute to better mentoring the next generations of neurologists.

\section{Study Funding}

The authors report no targeted funding.

\section{Disclosure}

S. Sandrone receives royalties from Oxford University Press (USA). D.V.F. Albert, S.R. Dunham, J. Kraker, I. Noviawaty, and M. Palm report no financial disclosures. H. Kushlaf has served as a consultant on advisory boards for Alexion Pharmaceuticals, Argenx, Catalyst Pharmaceuticals, and Sanofi Genzyme; and serves on the speaker bureaus of Akcea, Catalyst Pharmaceuticals, and Sanofi Genzyme. Go to Neurology. org/ $\mathrm{N}$ for full disclosures.

Appendix Authors

\begin{tabular}{lll}
\hline Name & Location & Contribution \\
\hline $\begin{array}{l}\text { Stefano } \\
\text { Sandrone, }\end{array}$ & Imperial & College \\
PhD & London role in designing and \\
& $\begin{array}{l}\text { conceptualizing the paper; drafted, } \\
\text { wrote, and revised different versions } \\
\text { of the manuscript for intellectual } \\
\text { content }\end{array}$ \\
\hline
\end{tabular}

\section{Appendix (continued)}

\begin{tabular}{|c|c|c|}
\hline Name & Location & Contribution \\
\hline $\begin{array}{l}\text { Dara V.F. } \\
\text { Albert, DO, } \\
\text { MEd }\end{array}$ & $\begin{array}{l}\text { The Ohio State } \\
\text { University }\end{array}$ & $\begin{array}{l}\text { Wrote a section of the manuscript and } \\
\text { revised a previous version of the } \\
\text { manuscript for intellectual content }\end{array}$ \\
\hline $\begin{array}{l}\text { S. Richard } \\
\text { Dunham, MD }\end{array}$ & $\begin{array}{l}\text { Washington } \\
\text { University }\end{array}$ & $\begin{array}{l}\text { Wrote a section of the manuscript and } \\
\text { revised a previous version of the } \\
\text { manuscript for intellectual content }\end{array}$ \\
\hline $\begin{array}{l}\text { Jessica } \\
\text { Kraker, MD }\end{array}$ & $\begin{array}{l}\text { Tulane } \\
\text { University }\end{array}$ & $\begin{array}{l}\text { Wrote a section of the manuscript and } \\
\text { revised a previous version of the } \\
\text { manuscript for intellectual content }\end{array}$ \\
\hline $\begin{array}{l}\text { Ika } \\
\text { Noviawaty, } \\
\text { MD }\end{array}$ & $\begin{array}{l}\text { University of } \\
\text { Massachusetts }\end{array}$ & $\begin{array}{l}\text { Wrote a section of the manuscript and } \\
\text { revised a previous version of the } \\
\text { manuscript for intellectual content; } \\
\text { drew the figure }\end{array}$ \\
\hline $\begin{array}{l}\text { Michael } \\
\text { Palm, MD }\end{array}$ & $\begin{array}{l}\text { UT Health San } \\
\text { Antonio }\end{array}$ & $\begin{array}{l}\text { Wrote a section of the manuscript and } \\
\text { revised a previous version of the } \\
\text { manuscript for intellectual content }\end{array}$ \\
\hline $\begin{array}{l}\text { Hani } \\
\text { Kushlaf, MD }\end{array}$ & $\begin{array}{l}\text { University of } \\
\text { Cincinnati }\end{array}$ & $\begin{array}{l}\text { Major role in designing and } \\
\text { conceptualizing the paper; drafted, } \\
\text { wrote, and revised different versions of } \\
\text { the manuscript for intellectual content }\end{array}$ \\
\hline
\end{tabular}

\section{References}

1. Sandrone S, Berthaud JV, Carlson C, et al. Strategic considerations for applying the flipped classroom to neurology education. Ann Neurol. 2020;87(1):4-9.

2. Weber DJ, Albert DV, Aravamuthan BR, Bernson-Leung ME, Bhatti D, Milligan TA. Training in Neurology: rapid implementation of cross-institutional neurology resident education in the time of COVID-19. Neurology. 2020;95(19): 883-886.

3. Ross DA; National Neuroscience Curriculum Initiative "Quarantine Curriculum" Committee. Creating a "quarantine curriculum" to enhance teaching and learning during the COVID-19 pandemic. Acad Med. 2020;95:1125-1126.

4. Yang L, Brown-Johnson CG, Miller-Kuhlmann R, et al. Accelerated launch of video visits in ambulatory neurology during COVID-19: key lessons from the Stanford experience. Neurology. 2020;95(7):305-311.

5. van der Meulen M, Kleineberg NN, Schreier DR, García-Azorin D, Di Lorenzo F. COVID-19 and neurological training in Europe: from early challenges to future perspectives. Neurol Sci. 2020;41(12):3377-3379.

6. Riley B, Packer M, Gallier S, Sapey E, Atkin C. Acute, non-COVID related medical admissions during the first wave of COVID-19: a retrospective comparison of changing patterns of disease. medRxiv. Preprint posted online September 18, 2020. doi:10.1101/2020.09.15.20194795

7. Sandrone S, Schneider LD. Active and distance learning in neuroscience education. Neuron. 2020;106(6):895-898.

8. Fraser H, Soanes K, Jones SA, Jones CS, Malishev M. The value of virtual conferencing for ecology and conservation. Conservation Biol. 2017;31(3):540-546.

9. Kabo FW, Cotton-Nessler N, Hwang Y, Levenstein MC, Owen-Smith J. Proximity effects on the dynamics and outcomes of scientific collaborations. Res Pol. 2014;43(9): 1469-1485.

10. Emanuel EJ. The inevitable reimagining of medical education. JAMA. 2020;323(12): $1127-1128$.

11. Levin KH, Shanafelt TD, Keran CM, et al. Burnout, career satisfaction, and well being among US neurology residents and fellows in 2016. Neurology. 2017;89(5): 492-501.

12. Kannampallil TG, Goss CW, Evanoff BA, Strickland JR, McAlister RP, Duncan J. Exposure to COVID-19 patients increases physician trainee stress and burnout. PLoS One. 2020;15(8):e0237301.

13. Spinelli C, Wisener M, Khoury B. Mindfulness training for healthcare professionals and trainees: a meta-analysis of randomized controlled trials. J Psychosomatic Res. 2019;120:29-38.

14. Hatcher-Martin JM, Adams JL, Anderson ER, et al. Telemedicine in neurology: telemedicine work group of the American Academy of Neurology update. Neurology. 2020;94(1):30-38.

15. Zha AM, Chung LS, Song SS, Majersik JJ, Jagolino-Cole AL. Training in Neurology: adoption of resident teleneurology training in the wake of COVID-19: telemedicine crash course. Neurology. 2020;95(9):404-407. 


\section{Neurology}

\section{Training in Neurology: How Lessons Learned on Teaching, Well-being, and Telemedicine During the COVID-19 Pandemic Can Shape the Future of Neurology Education}

Stefano Sandrone, Dara V.F. Albert, S. Richard Dunham, et al. Neurology 2021;96;e3007-e3010 Published Online before print April 28, 2021

DOI 10.1212/WNL.0000000000012010

\section{This information is current as of April 28, 2021}

\section{Updated Information \& Services}

References

Citations

Subspecialty Collections

Permissions \& Licensing

Reprints including high resolution figures, can be found at: http://n.neurology.org/content/96/24/e3007.full

This article cites 15 articles, 6 of which you can access for free at: http://n.neurology.org/content/96/24/e3007.full\#ref-list-1

This article has been cited by 1 HighWire-hosted articles: http://n.neurology.org/content/96/24/e3007.full\#\#otherarticles

This article, along with others on similar topics, appears in the following collection(s):

\section{All Education}

http://n.neurology.org/cgi/collection/all_education

Computer use in education

http://n.neurology.org/cgi/collection/computer_use_in_education COVID-19

http://n.neurology.org/cgi/collection/covid_19

Methods of education

http://n.neurology.org/cgi/collection/methods_of_education Other Education

http://n.neurology.org/cgi/collection/other_education

Information about reproducing this article in parts (figures,tables) or in its entirety can be found online at:

http://www.neurology.org/about/about_the_journal\#permissions

Information about ordering reprints can be found online:

http://n.neurology.org/subscribers/advertise

Neurology ${ }^{\circledR}$ is the official journal of the American Academy of Neurology. Published continuously since 1951, it is now a weekly with 48 issues per year. Copyright @ 2021 American Academy of Neurology. All rights reserved. Print ISSN: 0028-3878. Online ISSN: 1526-632X.

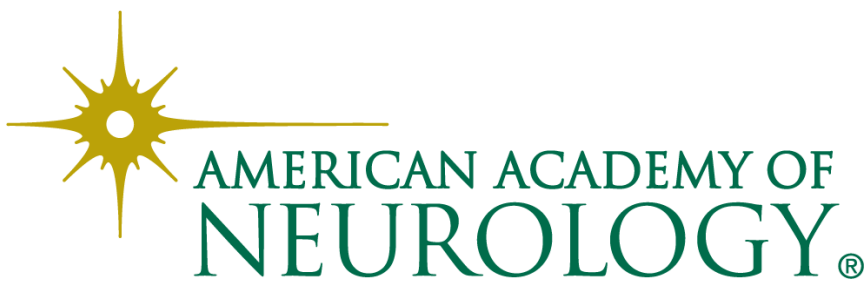

